Biotechnology

\title{
Insect virus as super-vector?
}

\section{Washington}

AN insect virus that could become a second-generation recombinant vector is gaining a quiet following in biotechnology. The baculovirus is easily engineered and achieves both high synthesis rates and complex processing of recombinant products. Cetus, Eli Lilly, Genentech and 15 other companies are investigating the system, but a three-year-old Connecticut company called MicroGeneSys claims it has already foiled the competition.

Although he heads only 25 employees, founder and president Frank Volvovitz believes MicroGeneSys has invested more time, money and expertise in the use of baculovirus than any other company. Volvovitz culled six virologists from laboratories at the National Institutes of Health, Baylor College of Medicine and Texas A\&M for his research team. The company will not disclose the yields it has achieved, but published reports contain examples of recombinant protein production nearing $700 \mathrm{mg}$ per litre of culture within a few days of infection. This rivals the rates of monoclonal antibody production by hybridomas, the most efficient recombinant machinery known.

The system is based on a cell line established in the late 1970 s from the pupal ovarian cells of the moth Spodoptera frugiperda. When infected with baculovirus carrying a foreign gene, these cells can secrete recombinant products complete with post-translational modifications such as phosphorylation and glycosylation. The system may therefore dispense with costly downstream processing. Mammalian cell cultures offer the same processing advantages, but are not as prolific.

The productivity of the baculovirus derives from the efficiency of the viral promotes of the gene encoding the protein called polyhedron, the sole component of a crystalline matrix that acts as a protective shield for viral particles existing outside their insect host. Caterpillars eat the matrix and release the particles, which then temporarily suspend polyhedron synthesis. When the caterpillar is near death, the virus resumes matrix protein production until roughly 20 per cent of the larval host consists of polyhedron.

MicroGeneSys has already harnessed this productivity for a hepatitis- $B$ vaccine which will enter clinical trials this fall. The company is also developing vaccines against acquired immune deficiency syndrome and malaria infections. Meanwhile, research in Texas A\&M and the University of Idaho is generating a network of academic and corporate collaboration on baculovirus technology.

Eli Lilly has been working closely with Max Summers in Texas, who is generally recognized as the technology's pioneer. Summer's laboratory is also working on interleukin-2 with Hoffman-LaRoche. Cetus is building on its preliminary results with colony-stimulating factor, while Genentech assigned a handful of researchers to investigate the system and says merely that it is "very interesting". Genetics Institute (which has just raised \$75 million in its first public offering of shares), had originally planned to use baculovirus for making pesticides, but changed the emphasis of its programme on learning more about the system.

There are some sceptics in the field as well. Chiron considers that the baculovirus has only "marginal utility" compared with its own yeast systems. Even the staunchest supporters of baculovirology admit that the analysis of the gene products so far has not been thorough enough to ensure smooth passage through the regulatory process. Little is known, for example, about the characteristics of the insect cell glycosylation, which could affect biological activity. Karen Wright

\section{European research}

\section{Still hope for budget increase}

Luxembourg

RESEARCH ministers of the twelve member states of the European Economic Community (EEC) meeting here last week refused to triple the research budget of EEC, demanding that the European Commission, which administers EEC affairs, be more "realistic" in its requests. The Commission, however, regards its proposal for an ECU (European Currency Unit) 10,350 million ( $£ 6,600$ million) "framework programme" of international research for 1987-91 as eminently realistic, and indeed vital for the economic future of Europe - and has retired to prepare a new proposal to put before the ministers in October.

But this apparently eyeball-to-eyeball confrontation is not official. It occurred over lunch - when no official minutes are taken. But the British, French and German delegations did not aid Commission digestions with their insistence on only small increases in the ECU 3,750 million five-year research budget of the $\mathrm{EEC}$.

The EEC spend is dwarfed by the ECU 150,000 million or so that the individual nation members of EEC spend on research each five years, and the Commission is arguing, in effect, that a great part of this national spending is wasted, either by duplication of effort or by a failure of research or technological enterprises to reach a critical mass of talent or investment. In its strategy to 1991 , the Commission aims to expand existing successful coordination programmes in areas such as information technology and biotechnology, and to turn pilot programmes into fully-fledged actions.

EEC research ministers, particularly in the larger European nations, are apparently holding back this expansion, or even if the research ministers are more willing to support the Commission over-zealous finance ministers in the newly monetarist France, in West Germany and the United Kingdom are putting the brakes on. Research ministers at a political level now strongly back the object- ives of "improving Europe's technological competitiveness" and of increasing the "cohesion" among individual national research and technology policies, two of the current "buzz phrases" in European science policy, but at an economic level the ministers seem unable or unwilling to back the principles with cash.

Meanwhile, Geoffrey Pattie, the British minister of technology, recommended that the Commission could save money on science, by cutting its energy research by 20 per cent (it is set to remain roughly constant in the new framework programme) or by offering only fractional subsidies (down to 25 per cent on a sliding scale from the current 50 per cent) to university, institutional and industrial projects granted EEC support, thus making a small sum go further. The Chernobyl reactor disaster may make the first unlikely, as projected decreases in nuclear fission safety research may have to be reversed; and according to Commission officials the second is already practised.

Pattie and other "purse-strings" ministers present, including Alain Devaquet from France and Heinz Reisenhuber from West Germany, made it plain that when the Commission returns with new proposals they must be realistic or further delays in agreeing the programme are inevitable. Everything rests on what "realistic" means, but estimates were ranging here from around ECU 4,300 million the sum estimated to be necessary to keep going with the present programme, to "around half" the proposed programme (some ECU 5,500 million). With these sums it would be possible to go ahead with the planned programme, according to Commission officials, but the number of grants awarded would be nowhere near able to satisfy the demand, the disappointment of good applicants would cause disillusion, and the function of the programme as a real catalyst of European economic and technological transformation would prove more difficult to achieve.

Robert Walgate 